\title{
PENGEMBANGAN MODUL BERORIENTASI POE (PREDICT, OBSERVE, EXPLAIN) BERWAWASAN LINGKUNGAN PADAMATERI PENCEMARAN UNTUK MENINGKATKAN HASIL BELAJAR SISWA
}

\author{
Ratna Widyaningrum ${ }^{1}$, Sarwanto $^{2}$, Puguh Karyanto ${ }^{3}$ \\ 1,2,3 Program Studi Pendidikan Sains Program Pascasarjana \\ Universitas Sebelas Maret Surakarta, 57126, Indonesia \\ E-mail : ratnawidya133@gmail.com
}

Diterima 02 Desember 2012, Disetujui 21 Januari 2013

\begin{abstract}
ABSTRAK- Penelitian ini bertujuan untuk mengetahui prosedur pengembangan modul berorientasi $P O E$ berwawasan lingkungan pada materi pencemaran, kelayakan modul, efektivitas modul, dan perbedaan hasil belajar siswa sebelum dan setelah penerapan modul. Penelitian ini menggunakan metode Research and Development (R\&D) yang mengacu pada model Borg \& Gall yang telah dimodifikasi. Sampel pengembangan meliputi sampel validasi produk sejumlah 4 validator, sampel uji coba terbatas pada 10 siswa, dan sampel uji coba lapangan sejumlah 32 siswa. Teknik pengumpulan data yang digunakan adalah angket untuk analisis kebutuhan, validasi ahli, dan tanggapan siswa terhadap modul; lembar observasi untuk hasil belajar psikomotorik, afektif, dan keterlaksanaan sintaks; wawancara untuk analisis kebutuhan, tanggapan siswa terhadap modul saat uji coba terbatas, dan lapangan; dan tes untuk hasil belajar kognitif. Uji coba lapangan menggunakan one group pretest-posttes design. Data hasil belajar kognitif dihitung dengan gain ternormalisasi dan diuji dengan uji t dua sampel berpasangan, sedangkan hasil belajar psikomotorik dan afektif dihitung persentase ketercapaiannya. Berdasarkan hasil penelitian dapat disimpulkan bahwa: pengembangan modul berorientasi $P O E$ berwawasan lingkungan pada materi pencemaran menggunakan model Borg \& Gall yang telah dimodifikasi melalui tahapan research and information collection, planning, developpreliminary form of products, preliminary field testing, main product revision, main field testing, dan operational product revision; kelayakan modul bernilai 3,3 setelah dilakukan uji lapangan dan berkategori "Baik"; pencapaian hasil belajar siswa mengalami peningkatan yang signifikan dalam kategori "Sedang"; dan setelah dilakukan uji secara statistik diperoleh perbedaan hasil belajar siswa
\end{abstract}

Kata Kunci: Modul, $P O E$, Lingkungan, Hasil Belajar

\section{Pendahuluan}

Pembelajaran sains pada

hakikatnya terdiri atas produk, proses, dan sikap yang menuntut siswa melakukan penemuan dan pemecahan masalah. Sains menurut Mundilarto (2005: 2), memiliki fungsi yang sangat strategis karena dapat

dipergunakan untuk mengembangkan potensi dan kemampuan-kemampuan siswa baik aspek kognitif, aspek psikomotorik, maupun aspek afektif. Jadi, di samping bersifat transfer ilmu 
pengetahuan dan keterampilan, pembelajaran sains seharusnya juga digunakan untuk menanamkan serta mengembangkan sikap dan nilai-nilai ilmiah seperti kejujuran, kedisiplinan, kecermatan, objektivitas, kreativitas, serta cara-cara berpikir yang efektif dan efisien. Kemampuan-kemampuan tersebut tidak mungkin dapat berkembang dengan sendirinya tanpa adanya bimbingan dan arahan secara intensif dari guru melalui pembelajaran sains yang bersifat inovatif serta akomodatif. Oleh karena itu, sains sebaiknya dipelajari dengan cara-cara yang memungkinkan berkembangnya keterampilan berpikir dalam pemecahan masalah-masalah nyata.

Biologi merupakan salah satu bagian dari sains yang memiliki kajian cukup luas karena terdiri dari berbagai konsep tentang kehidupan. Berdasarkan kenyataan ini, guru seharusnya dapat mengupayakan dan menanamkan kepada siswa untuk mempelajari biologi dengan memahami konsep-konsep yang ada. Konsep-konsep dalam biologi erat kaitannya dengan kehidupan sehari-hari sehingga mengaitkan konsep biologi dengan kehidupan sehari-hari akan membuat pembelajaran lebih bermakna dan bukan sekedar pembelajaran yang hafalan. Oleh karena itu, guru harus memiliki kompetensi untuk mengembangkan pembelajaran.

Menurut Sungkono (2003: 1), salah satu kompetensi yang perlu dimiliki seorang guru dalam melaksanakan tugasnya adalah mengembangkan bahan ajar. Pengembangan bahan ajar penting dilakukan guru agar pembelajaran lebih efektif, efisien, serta sesuai dengan kompetensi yang ingin dicapai. Hal tersebut sesuai dengan Permendiknas nomor 16 tahun 2007 yang mengatur tentang Standar Kualifikasi Akademik dan Kompetensi Guru, yaitu bagi guru pada satuan pendidikan jenjang Sekolah Menengah Atas (SMA), baik dalam tuntutan kompetensi pedagogik maupun profesional berkaitan erat dengan kemampuan guru dalam mengembangkan sumber belajar dan bahan ajar (Depdiknas, 2008: 1).

Kompetensi mengembangkan bahan ajar idealnya telah dikuasai guru, tetapi pada kenyataannya masih banyak guru yang belum menguasai kompetensi tersebut dengan baik. Guru pada umumnya lebih mengandalkan bahan ajar yang berasal dari penerbit, baik berupa buku ajar ataupun LKS yang berisi latihan soal. Selain itu, proses pembelajaran masih banyak dilakukan secara konvensional yaitu dengan metode ceramah. Dampak dari pembelajaran konvensional ini antara lain, aktivitas guru lebih dominan dan 
sebaliknya siswa kurang aktif karena lebih cenderung menjadi pendengar. Disamping itu, pembelajaran yang dilakukan menjadi kurang variatif sehingga mengakibatkan kualitas pembelajaran di sekolah kurang optimal. Hal tersebut sesuai dengan penelitian yang dilakukan oleh Wenno (2010: 177), yang menyatakan bahwa masih banyak guru sains yang berpendapat bahwa mengajar itu suatu kegiatan menjelaskan dan menyampaikan informasi tentang konsep-konsep. Pengajaran sains di sekolah umumnya dilakukan dengan cara menghafal dan sangat minim dengan kerja laboratorium. Prastowo (2012: 14) mengemukakan bahwa guru belum mengembangkan kreativitas untuk menyiapkan dan membuat bahan ajar secara mandiri dan memilih bahan ajar yang siap pakai karena beranggapan bahwa membuat bahan ajar merupakan pekerjaan yang sulit dan membutuhkan waktu yang lama.

Menurut data dari PISA, rata-rata skor prestasi literasi sains siswa Indonesia berada signifikan di bawah rata-rata internasional. Rata-rata skor prestasi literasi sains Indonesia pada tahun 2000 dan 2003 berada di peringkat ke-38 dari 40 negara, pada tahun 2006 berada di peringkat ke-50 dari 57 negara, dan pada tahun 2009 Indonesia berada pada peringkat 60 dari 65 negara. Aspek literasi sains yang diukur adalah menggunakan pengetahuan dan mengidentifikasi masalah untuk memahami fakta-fakta dan membuat keputusan tentang alam serta perubahan yang terjadi pada lingkungan. Hasil studi tersebut diharapkan dapat digunakan sebagai masukan dalam perumusan kebijakan untuk peningkatan kualitas pendidikan dan pembelajaran.

Peningkatan kualitas proses pembelajaran di sekolah dapat dilakukan dengan berbagai strategi, salah satu alternatif yang dapat ditempuh adalah pengembangan bahan ajar. Saat ini pengembangan bahan ajar menjadi kebutuhan yang mendesak karena dalam Kurikulum Tingkat Satuan Pendidikan (KTSP) menuntut pendidik agar mampu mengembangkan bahan ajar sendiri. Salah satu bentuk bahan ajar yang dapat dikembangkan adalah modul. Modul dapat membantu sekolah dalam mewujudkan pembelajaran yang berkualitas. Penerapan modul dapat mengkondisikan kegiatan pembelajaran lebih terencana dengan baik, mandiri, tuntas, dan dengan hasil (output) yang jelas.

Modul merupakan salah satu bentuk bahan ajar yang dikemas secara utuh dan sistematis, didalamnya memuat seperangkat pengalaman belajar yang terencana dan didesain untuk membantu peserta didik menguasai tujuan belajar 
yang spesifik (Depdiknas, 2008: 4). Modul pembelajaran yang beredar saat ini sudah banyak. Namun, modul tersebut belum mengoptimalkan kemampuan siswa dalam memecahkan permasalahan yang berkaitan dengan kehidupan sehari-hari. Suratsih (2010: 3) mengemukakan bahwa modul yang tersedia di sekolah hanya berisi materi umum yang sebenarnya telah banyak dikembangkan dalam buku-buku pelajaran. Selain itu, guru masih banyak menggunakan sumber belajar yang tersedia di pasaran yang tidak sesuai dengan kondisi dan potensi sekolah maupun karakteristik siswa. Millah dkk. (2012: 20) mengemukakan bahwa berdasarkan hasil pengamatan, bahan ajar yang beredar di pasaran masih terdapat kekurangan karena bahan ajar tersebut belum merancang siswa untuk berpikir tingkat tinggi dalam memecahkan permasalahan autentik dalam kehidupan sehari-hari serta mengaitkannya dengan masyarakat dan lingkungan. Salah satu model pembelajaran yang berpotensi melatihkan siswa untuk memecahkan permasalahan adalah Predict, Observe, Explain (POE).

Model POE merupakan rangkaian proses pemecahan masalah yang dilakukan oleh siswa melalui tahap prediksi atau membuat dugaan awal (predict), pengamatan atau pembuktian dugaan (observe), serta penjelasan terhadap hasil pengamatan (explain). Menurut Ozdemir dkk. (2011: 1) POE dapat meningkatkan pemahaman konsep sains siswa. Model ini dapat digunakan untuk menggali pengetahuan awal siswa, memberikan informasi kepada guru mengenai kemampuan berpikir siswa, mengkondisikan siswa untuk melakukan diskusi, memotivasi siswa untuk mengeksplorasi konsep yang dimiliki, dan membangkitkan siswa untuk melakukan investigasi. Model ini merupakan salah satu model berorientasi konstruktivisme yang menekankan pada cara siswa membangun atau menemukan pengetahuan sendiri. Model ini melatihkan siswa untuk memberikan prediksi atau jawaban sementara dari permasalahan yang diberikan oleh guru.

Permasalahan yang diberikan oleh guru berkisar tentang fenomena atau isuisu lingkungan di sekitar. Mengaitkan fenomena atau isu-isu lingkungan dalam suatu proses belajar merupakan salah satu bentuk pendekatan pembelajaran. Pendekatan ini menjadikan lingkungan sebagai sumber belajar, sehingga sesuai untuk diaplikasikan pada materi yang berkaitan dengan kehidupan sehari-hari, salah satunya adalah materi Pencemaran Lingkungan. Berdasarkan hasil Ujian Nasional (UN) 2011/2012 menunjukkan bahwa pada materi Pencemaran khususnya 
pada indikator "mendeskripsikan konsep keseimbangan lingkungan dan pelestariannya", rata-rata skor yang diperoleh siswa SMA Negeri 7 Surakarta adalah 50,81 dan untuk tingkat kabupaten/kota rata-ratanya adalah 64,29. Hal tersebut menunjukkan hasil belajar siswa khususnya pada materi Pencemaran masih rendah. Salah satu upaya yang dapat dilakukan untuk meningkatkan hasil dan kualitas pembelajaran khususnya pada materi tersebut adalah dengan penyajian permasalahan untuk dipecahkan oleh siswa. Permasalahan lingkungan dapat diambil dari daerah sekitar, khususnya di karesidenan Surakarta. Menurut Johnson dan Johnson cit. Gulo (2008: 116) permasalahan yang dipilih merupakan masalah yang dianggap penting yang bersifat konflik, dan dapat diambil dari kliping atau peristiwa-peristiwa di sekitar siswa. Permasalahan diperlukan untuk membangun kecakapan siswa agar konsepkonsep yang ada dalam modul tersebut dapat diterapkan dalam kehidupan seharihari. Oleh karena itu, perlu dikembangkan modul berwawasan lingkungan yang dapat menunjang belajar siswa dan dirancang agar siswa memecahkan masalah dalam kehidupan sehari-hari serta menerapkannya dalam masyarakat dan lingkungan.

Modul berorientasi POE berwawasan lingkungan ini mempunyai beberapa kelebihan dari modul yang sudah terdapat di pasaran karena menekankan pada pemecahan masalah sehari-hari serta mengangkat permasalahan lingkungan yang ada sekitar khususnya di daerah Surakarta. Proses pemecahan masalah ini dilakukan melalui tiga tahapan yaitu, siswa diminta untuk melakukan prediksi atau dugaan awal terhadap fenomena biologi (predict), pengamatan atau pembuktian dugaan (observe), serta menjelaskan hasil pengamatan (explain). Sebelum tahap predict disajikan asah pemahaman dan wacana untuk menggali pengetahuan awal siswa dan memperkuat konsep. Setelah siswa memperoleh konsep awal, disajikan permasalahan mengenai pencemaran lingkungan sekitar, kemudian siswa diminta untuk melakukan prediksi terhadap fenomena tersebut. Selain itu, pada tahap prediksi juga dilengkapi dengan gambar/ilustrasi sehingga dapat menarik rasa ingin tahu siswa. Tahap observe berupa percobaan sederhana yang terdiri dari alat dan bahan, rancangan percobaan, dan Lembar Kerja Siswa (LKS) untuk melakukan pemecahan masalah sedangkan pada tahap explain siswa diminta menjelaskan hasilobservasi atau eksperimen. Modul ini juga dilengkapi dengan info sains yang berisi materi, rangkuman, wawasan sains baik berupa informasi atau penemuan yang berkaitan dengan materi, evaluasi, petunjuk penilaian, refleksi diri, dan tugas 
individu sehingga modul ini akan bermanfaat dalam pembelajaran.

Pembelajaran sains dengan menggunakan bahan ajar modul sangat bermanfaat bagi guru karena siswa akan lebih kreatif dalam mengembangkan dirinya, kegiatan pembelajaran menjadi lebih menarik, siswa akan lebih banyak mendapatkan kesempatan untuk belajar secara mandiri, mengurangi ketergantungan terhadap kehadiran guru sains, dan siswa juga akan mendapatkan kemudahan dalam mempelajari setiap kompetensi yang harus dikuasainya (Wenno, 2010: 179). Selain dapat digunakan untuk belajar secara mandiri, modul ini jugabermanfaat untuk mengoptimalkan belajar dalam bentuk diskusi karena siswa akan dituntut untuk memecahkan masalah secara kelompok dan melakukan percobaan di dalam kelompok. Budiono dan Susanto (2006: 86) mengemukakan bahwa cara yang makin baik dalam menggunakan modul adalah siswa aktif mempelajarinya bersama dengan teman sementara guru melakukan pengecekan secara intensif dan memberikan bantuan kepada siswa yang kesulitan dalam mempelajari modul secara individual.

\footnotetext{
Ketersediaan bahan ajar yang sesuai dengan potensi sekolah dan karakteristik siswa berpengaruh terhadap hasil belajar siswa. Belum tersedianya
}

modul yang secara spesifik mengulas tentang berbagai macam permasalahan lingkungan khususnya di daerah Surakarta, menyebabkan siswa menjadi dominan mengandalkan sumber belajar hanya berupa buku paket, LKS, dan catatan sehingga berdampak pada hasil belajar siswa yang menjadi kurang optimal. Sumber belajar berupa buku paket tersebut lebih menonjolkan mengenai materi pelajaran tetapi belum melatihkan siswa untuk pemecahan masalah melalui kerja ilmiah sedangkan LKS yang dimiliki siswa kebanyakan hanya berupa rangkuman materi dan latihan soal-soal. Prastowo (2012: 18) mengemukakan bahwa bahan ajar yang siap pakai sekarang ini kurang kontekstual, kurang menarik, dan mungkin tidak sesuai dengan kebutuhan serta karakteristik siswa. Hal tersebut diperkuat dengan pernyataan oleh Depdiknas (2003: 2) yang mengemukakan bahwa kualitas buku pelajaran sains di lapangan, ditinjau dari segi jumlah, jenis, maupun kualitasnya sangat bervariasi, tidak jarang ditemukan buku teks yang tidak sesuai dengan kurikulum.

Tujuan penelitian adalah untuk mengetahui: 1) hasil prosedur pengembangan modul berorientasi POE berwawasan lingkungan pada materi pencemaran, 2) kelayakan modul berorientasi POE berwawasan lingkungan pada materi 
pencemaran, 3) efektivitas modul berorientasi $P O E$ berwawasan lingkungan pada materi pencemaran, dan 4) perbedaan hasil belajar siswa sebelum dan setelah penerapan modulberorientasi $P O E$ berwawasan lingkungan pada materi pencemaran.

\section{Metode Penelitian}

Penelitian ini dilaksanakan di SMAN 7 Surakarta. Waktu pelaksanaan di semester II Tahun Pelajaran 2012-2013, bulan Mei 2013. Jenis penelitian ini adalah penelitian dan pengembangan (research and development). Prosedur pengembangan dari penelitian adalah model prosedural yang dimodifikasi dari model pengembangan Borg \& Gall dan dilakukan hanya sampai pada tahap ketujuh.

Tahapan penelitian dan pengembangan ini adalah: 1) research and information collecting, yaitu penelitian dan pengumpulan informasi. Tahap tersebut meliputi: studi pustaka, observasi di lapangan, wawancara, dan persiapan untuk merumuskan kerangka kerja penelitian; 2) planning, yaitu perencanaan. Tahap tersebut merupakan tahap penyusunan rencana penelitian yang meliputi, merumuskan tujuan, desain atau langkah-langkah penelitian, dan penyusunan modul (draft I); 3) develop preliminary form of product, yaitu mengembangkan bentuk permulaan dari produk yang akan dihasilkan, termasuk dalam langkah ini adalah pengujian produk draft I oleh ahli dan praktisi serta revisi I; 4) preliminary field testing, yaitu melakukan uji coba lapangan awal dalam skala terbatas, melibatkan 1 sekolah dengan jumlah 10 subyek. Pengumpulan dan analisis data dapat dilakukan dengan cara wawancara, observasi, dan angket; 5) mainproduct revision, yaitu melakukan perbaikan terhadap produk awal yang dihasilkan berdasarkan hasil uji coba awal. Perbaikan ini dilakukan sesuai dengan hasil yang ditunjukkan dalam uji coba terbatas, sehingga diperoleh draft produk (model) utama yang siap diuji coba lebih luas (draft II); 6) main field testing, yaitu uji lapangan yang melibatkan 1 sekolah, dengan jumlah subyek 32 siswa. Uji coba lapangan menggunakan quasi eksperimen dengan desain penelitian One Group Pretest Postes Design ; 7) operational product revision, yaitu melakukan perbaikan/penyempurnaan terhadap hasil uji coba lapangan.

Teknik pengumpulan data yang digunakan adalah angket untuk analisis kebutuhan, validasi ahli, dan tanggapan siswa terhadap modul; lembar observasi untuk hasil belajar psikomotorik, afektif, dan keterlaksanaan sintaks; wawancara untuk analisis kebutuhan, tanggapan siswa terhadap modul saat uji coba terbatas, dan lapangan; dan tes untuk hasil belajar 
kognitif. Instrumen dalam penelitiaan ini terbagi menjadi dua yaitu: instrumen pelaksanaan penelitian dan instrumen pengambilan data. Instrumen tersebut sebelumnya telah divalidasi oleh ahli dan praktisi pembelajaran. Instrumen pelaksanaan penelitian meliputi silabus, RPP, modul, instrumen penilaian kognitif, afektif, dan psikomotorik. Instrumen pengambilan data meliputi angket analisis kebutuhan untuk sekolah, guru, dan siswa, serta angket penilaian modul;. Sebelum melaksanakan tes, instrumen tes kognitif diuji cobakan terlebih dahulu untuk mengetahui validitas, reliabilitas, daya beda, dan taraf kesukaran dari tes tersebut.

Data analisis kebutuhan dianalisis secara kualitatif. Analisis data penilaian ahli mengenai pengembangan modul berorientasi $P O E$ berwawasan lingkungan dilakukan dengan teknik analisa kualitatif dan analisa kuantitatif. Data yang berupa skor diubah menjadi data kualitatif (data interval) dengan skala empat. Data kualitatif yang diperoleh pada saat uji coba skala kecil berupa wawancara dianalisis secara kualitatif, sedangkan data yang berupa angket dikonversi ke dalam skala empat. Data uji coba lapangan meliputi hasil belajar kognitif, afektif, dan psikomotorik. Efektivitas modul terlebih dahulu dihitung dengan teknik normalized gain untuk mengetahui peningkatanhasil belajar siswa. Selanjutnya, data hasil belajar kognitif diuji untuk mengetahui taraf signifikansi pengaruh pembelajaran menggunakan modul berorientasi POE berwawasan lingkungan pada materi pencemaran terhadap hasil belajar siswa dengan paired sample t-test, yang sebelumnya telahdiuji prasyarat untuk engetahui normalitas dan homogenitas data.

\section{Hasil Penelitian dan Pembahasan}

Data yang diperoleh dalam penelitian ini adalah data analisis kebutuhan, data validasi ahli dan praktisi, data hasil uji coba terbatas,dan data hasil uji coba lapangan. Data hasil analisis kebutuhan berupa perbandingan pencapaian skor pada materi pencemaran di beberapa sekolah di Surakarta disajikan pada Tabel 1.

Tabel 1. Perbandingan Pencapaian Skor Materi Pencemaran

\begin{tabular}{lc}
\hline \multicolumn{1}{c}{ Sekolah } & Skor Pencapaian \\
\hline SMA Negeri 2 Surakarta & 60,00 \\
SMA Negeri 6 Surakarta & 53,85 \\
SMA Negeri 7 Surakarta & 50,81 \\
SMA Negeri 8 Surakarta & 54.68 \\
SMA Al Islam 1 & \\
Surakarta & 64,66 \\
SMA Batik 1 Surakarta & 57,69 \\
\hline
\end{tabular}

Tabel 1 menunjukkan bahwa nilai pada materi pencemaran di SMAN 7 Surakarta dan beberapa sekolah lain masih rendah. Hal tersebut terjadi karena dalam proses pembelajarannya siswa jarang diajak untuk belajar 
penemuan dan diskusi. Biologi, terutama pada materi pencemaran sangat erat kaitannya dengan keseharian siswa, sehingga akan lebih baik jika siswa diberikan dorongan untuk belajar dari permasalahan yang ada di lingkungan mereka. Hal tersebut sesuai dengan teori belajar yang disampaikan oleh Bruner, yang menyatakan bahwa belajar merupakan suatu proses aktif yang memungkinkan manusia untuk menemukan hal-hal baru di luar informasi yang diberikan kepada dirinya. Konsepnya adalah belajar dengan menemukan (discovery learning). Guru harus memberikan keleluasaan kepada siswa untuk menjadi pemecah masalah. Siswa didorong untuk belajar sendiri melalui kegiatan dan pengalaman. Hal tersebut diperkuat oleh pendapat Dahar cit. Triyanto (2010: 38), yang menyatakan bahwa berusaha sendiri untuk mencari pemecahan masalah serta pengetahuan yang menyertainya akan menghasilkan pengetahuan yang benar-benar bermakna. Selain itu, berdasakan kerucut pengalaman yang dipaparkan oleh Dale, pengalaman langsung akan memberikan kesan paling utuh dan paling bermakna mengenai informasi dan gagasan yang terkandung daam pengalaman tersebut karena melibatkan indera penglihatan, pendengaran, perasaaan, penciuman, dan peraba. Hal tersebut dikenal dengan istilah learning by doing.

Berdasarkan analisis mengenai beberapa modul yang ada, diperoleh hasil bahwa materi dalam modul tersebut sudah lengkap juga disertai dengan contohcontoh yang bersifat umum. Namun, modul tersebut lebih dominan pada materi dan latihan soal, belum mengoptimalkan siswa memecahkan masalah melalui diskusi dan eksperimen, serta mengaplikasikan dalam kehidupan seharihari siswa. Modul juga tidak dilengkapi dengan warna, gambar/simbol dan bahasa yang digunakan kurang komunikatif. Terdapat beberapa modul yang tidak mencantumkan instruksi yang lengkap, tidak terdapat peta konsep, serta belum disertai kunci jawaban dan pembahasan. Modul tersebut umumnya belum disesuaikan dengan potensi sekolah dan potensi lingkungan di sekitar siswa serta karakteristik siswa.Hal tersebut sesuai dengan pendapat Suratsih (2010: 3), yang mengemukakan bahwa modul yang tersedia di sekolah hanya berisi materi umum yang sebenarnya telah banyak dikembangkan dalam buku-buku pelajaran. Selain itu, guru masih banyak menggunakan sumber belajar yang tersedia di pasaran yang tidak sesuai dengan kondisi dan potensi sekolah maupun karakteristik siswa. Hal senada juga dikemukakan Millah dkk. (2012: 20), bahwa berdasarkan hasil 
pengamatan, bahan ajar yang beredar di pasaran masih terdapat kekurangan, karena bahan ajar tersebut belum merancang siswa untuk berpikir tingkat tinggi dalam memecahkan permasalahan autentik dalam kehidupan sehari-hari serta mengaitkannya dengan masyarakat dan lingkungan.

Hasil observasi dan wawancara terhadap guru dan siswa diperoleh gambaran awal tentang proses kegiatan belajar mengajar sebagai berikut yaitu pembelajaran yang dilakukan oleh guru cenderung menggunakan metode ceramah dan didominasi kegiatan presentasi individu atau kelompok oleh siswa. Trianto (2009: 75), mengemukakan bahwa pembelajaran yang bermakna tidak akan terwujud jika siswa hanya mendengarkan ceramah dari guru. Perangkat pembelajaran yang dimiliki guru sudah cukup lengkap yaitu silabus, RPP, LKS, dan buku ajar. Guru sudah membuat silabus dan RPP sendiri, tetapi guru belum mengembangkan bahan ajar secara mandiri. Biasanya guru menggunakan LKS dan buku ajar yang berasal dari penerbit. Menurut Sungkono (2003: 1), salah satu kompetensi yang perlu dimiliki seorang guru dalam melaksanakan tugasnya adalah mengembangkan bahan ajar. Hal tersebut diperkuat oleh pernyataan Depdiknas (2008: 1) yang mengemukakan bahwa Permendiknas nomor 16 tahun 2007 mengatur tentang Standar Kualifikasi Akademik dan Kompetensi Guru, yaitu bagi guru pada satuan pendidikan jenjang Sekolah Menengah Atas (SMA), baik dalam tuntutan kompetensi pedagogik maupun profesional berkaitan erat dengan kemampuan guru dalam mengembangkan sumber belajar dan bahan ajar. Berdasarkan hasil wawancara juga diperoleh informasi bahwa siswa mengalami kesulitan dan kurang tertarik mempelajari biologi sehingga mengakibatkan hasil belajar siswa masih rendah, dan setiap diadakan ulangan harian banyak siswa yang nilainya di bawah KKM.

Hasil validasi ahli dan praktisi mengenai penilaian modul (aspek materi, keterbacaan, dan penyajian) disajikan pada Tabel 2.

Tabel 2. Hasil Validasi Ahli dan Praktisi

\begin{tabular}{lccc}
\hline Validator & $\begin{array}{c}\text { Aspek } \\
\text { Materi }\end{array}$ & $\begin{array}{c}\text { Aspek } \\
\text { Keterbacaan }\end{array}$ & $\begin{array}{c}\text { Aspek } \\
\text { Penyajian }\end{array}$ \\
\hline Ahli & 3,17 & 3,36 & 3,2 \\
Praktisi & 3,75 & 3,87 & 3,96 \\
\hline
\end{tabular}

Tabel 2 menunjukkan penilaian modul yang dilakukan oleh ahli dan praktisi yang memperoleh hasil bahwa modul dalam kategori“Baik” untuk penilaian ahli, dan kategori "Sangat Baik" untuk penilaian praktisi.

Perbaikan telah dilakukan sesuai 
dengan saran dan masukan dari ahli. Materi telah ditambahkan sesuai dengan perkembangan IPTEK dengan bahasa yang lebih komunikatif disertai dengan contohcontoh sehingga siswa mudah memahami. Sumber dan catatan kaki telah ditambahkan, peta konsep dibuat per sub bab, dan diberikan gambaran umum penggunaan modul bagi siswa dan guru. Setiap komponen modul sudah diberikan gambar atau simbol supaya lebih menarik. Hal tersebut sesuai dengan yang dikemukakan oleh Prastowo (2012: 125), yang menyatakan bahwa gambar-gambar dapat mendukung dan memperjelas isi materi sehingga menimbulkan daya tarik dan mengurangi kebosanan bagi pembaca.

Uji terbatas dihasilkan penilaian kelayakan modul oleh siswa. Hasil penilaian tersebut disajikan pada Tabel 3.

\section{Tabel 3. Hasil Penilaian Modul Uji Coba} Terbatas

\begin{tabular}{lrc}
\hline No. Aspek & Rata-rata & Kategori \\
1. Materi & 3,36 & Baik \\
2. Penyajian & 3,53 & Sangat Baik \\
3. Keterbacaan & 3,53 & Sangat Baik
\end{tabular}

Berdasarkan hasil validasi siswa tentang penilaian modul, modul memiliki kategori yang sangat baik. Namun, masih memerlukan beberapa perbaikan. Perbaikan telah dilakukan sesuai dengan saran dan masukan dari ahli. Materi telah diperbaiki dan gambar dibuat lebih jelas. Depdiknas (2008: 6) menyatakan bahwa dalam penyusunan materi harus memperhatikan kedalaman dan keluasan cakupan materi. Keluasan materi menggambarkan seberapa banyak materi-materi yang dimasukkan, sedangkan kedalaman materi menyangkut rincian konsepkonsep yang terkandung di dalamnya, yang harus dipelajari oleh siswa. Materi pembelajaran perlu diidentifikasi secara tepat agar pencapaian kompetensi siswa dapat diukur. Selain itu, dengan mengidentifikasi jenis-jenis materi yang akan dibelajarkan, guru akan mendapatkan ketepatan dalam pemilihan metode pembelajaran.

Uji lapangan diperoleh data tentang penilaian modul, hasil belajar kognitif, psikomotorik, dan afektif siswa. Nilai pretes dan postes dihitung tingkat kenaikan hasil belajarnya untuk mengetahui efektifitas pembelajaran dengan modul. Rumus yang digunakan adalah rumus $N$-gain ternormalisasi. Hasil perhitungan $\mathrm{N}$-gain ternormalisasi diperoleh rata-rata kenaikan hasil belajar dari 32 orang siswa adalah 0,45. Berdasarkan kriteria Hake (1998: 1), menunjukkan bahwa kenaikan hasil belajar siswa dalam kategori“Sedang “. 
Data penilaian siswa terhadap modul disajikan pada Tabel 4 dan data hasil analisis nilai pretes dan postes siswa disajikan pada Tabel 5.

Tabel 5 menunjukkan bahwa Ho ditolak sehingga terdapat perbedaan nilai hasil belajar siswa sebelum diberikan modul pembelajaran dengan nilai hasil belajar siswa setelah diberikan modul pembelajaran. Merujuk pada hasil analisis tersebut maka dapat disimpulkan bahwa pemberian modul berorientasi POE berwawasan lingkungan pada materi pencemaran ini dapat meningkatkan hasil belajar kognitif siswa. Berdasarkan mean \pm SD diperoleh bahwa rata-rata nilai postes $(81,44)$ lebih tinggi daripada nilai pretes $(61,41)$, sehingga dapat disimpulkan bahwa hasil belajar siswa semakin baik atau mengalami peningkatan.

Terdapat kenaikan hasil belajar kognitif siswa, yang dapat dilihat dari nilai rata-rata siswa saat pretes dan postes. Penggunaan modul $P O E$ yang menuntut siswa untuk melakukan prediksi, observasi, dan menjelaskan hasil obeservasi akan membantu siswa dalam berbagai bentuk belajar, dengan demikian siswa akan lebih mudah memahami materi dan berperan aktif selama proses pembelajaran. Hal tersebut sesuai dengan penelitian yang dilakukan oleh Juniati (2009: 39), diperoleh hasil bahwa pembelajaran dengan strategi Probex memberikan motivasi kepada siswa, dapat memperlancar pembelajaran fisika, meningkatkan kerja sama siswa, dan hasil belajar siswa dapat mencapai taraf penguasaan yang optimal. Pembelajaran membuktikan prediksi, berdiskusi, dan komunikatif dalam menjelaskan hasil eksperimen, sehingga hal tersebut mendorong peningkatan hasil belajar siswa.

Data hasil belajar psikomotorik dan afektif disajikan berurutan pada Tabel 6 dan Tabel 7. 
Tabel 4. Hasil Analisis Angket Penilaian Modul

\begin{tabular}{llcc}
\hline No. & \multicolumn{1}{c}{ Aspek } & Rata-rata & Kategori \\
\hline 1. & Materi & 3,3 & Baik \\
2. & Penyajian & 3,3 & Baik \\
3. & Keterbacaan & 3,2 & Baik \\
\hline
\end{tabular}

Tabel 5. Hasil Analisis Nilai Pretes dan Postes

\begin{tabular}{cclcc}
\hline Uji & Jenis Uji & Hasil & Keputusan & Kesimpulan \\
& & & & \\
\hline Normalitas & Kolmogo- & Sig pretes= & Ho diterima & Data normal \\
& rof-Smirnov & 0,133 & & \\
& & Sig postes $=$ & & \\
Homogenitas & Levene's test & Sig 0.375 & Ho diterima & Data homogen \\
Hasil Pretes- & Paired & $\mathrm{t}_{\text {hitung }}=-7,645$ & Ho ditolak & Hasil tidak \\
Postes & sample & $\mathrm{p}=0,00$ & & sama (ada \\
& t-test & & & beda) \\
& & & & \\
\hline
\end{tabular}

Tabel 6. Persentase Hasil Belajar Psikomotorik

\begin{tabular}{cccc}
\hline $\begin{array}{c}\text { Jumlah } \\
\text { Siswa }\end{array}$ & $\begin{array}{c}\text { Pertemuan I } \\
(\boldsymbol{\%})\end{array}$ & $\begin{array}{c}\text { Pertemuan } \\
\text { II }(\%)\end{array}$ & $\begin{array}{c}\text { Pertemuan } \\
\text { III } \\
(\%)\end{array}$ \\
\hline 32 & 87,34 & 89,45 & 89,84 \\
\hline \multicolumn{4}{c}{ Tabel 7. Persentase Hasil Belajar Afektif } \\
\hline Jumlah & $\begin{array}{c}\text { Pertemuan I } \\
(\%)\end{array}$ & $\begin{array}{c}\text { Pertemuan } \\
\text { II }(\%)\end{array}$ & $\begin{array}{c}\text { Pertemuan } \\
\text { III } \\
(\%)\end{array}$ \\
\hline 32 & 81,51 & 84,11 & 84,4 \\
\hline
\end{tabular}


Berdasarkan Tabel 6 dan Tabel

7 tersebut menunjukkan bahwa hasil belajar psikomotor dan afektif siswa termasuk dalam kategori "Sangat Baik". Hasil belajar psikomotor mengalami kenaikan pada tiap pertemuan karena siswa telah terbiasa dengan metode praktikum, maka keterampilan siswa dalam penggunaan alat juga semakin baik. Depdiknas (2003: 7) mengemukakan bahwa pelajaran sains memfokuskan kegiatan pada penemuan dan pengolahan informasi melalui kegiatan mengamati, mengukur, mengajukan pertanyaan, mengklasifikasi, memecahkan masalah, dan sebagainya. Hal senada juga dikemukakan oleh Rahayu dkk (2013: 133), bahwa nilai rata-rata aspek psikomotorik mengalami peningkatan karena peserta didik terlibat aktif dan lebih terarah saat praktikum. Model POE menjadikan peserta didik lebih siap saat akan praktikum karena sebelumnya peserta didik harus membaca teori sehingga dapat membuat prediksi yang rasional. Selain itu, peserta didik juga berinteraksi dengan alat dan bahan, sehingga peserta didik dapat menguji prediksi melalui pengamatan (observe) dan mengemukakan penjelasan tentang fenomena yang mereka hadapi (explain).
Berdasarkan hasil analisis, nilai afektif siswa mengalami peningkatan. Hal tersebut terjadi karena siswa mulai terbiasa dengan modul yang dikembangkan. Siswa jugalebih aktif bekerja sama dengan teman saat praktikum dan diskusi. Depdiknas (2003: 6) mengemukakan bahwa diskusi merupakan salah satu kondisi belajar yang sesuai dengan filosofi konstruktivisme karena dalam diskusi siswa dapat mengunggkapkan gagasan, melakukan penelitian secara sederhana, demonstrasi, juga kegiatan lain yang memberikan ruang kepada siswa untuk dapat mempertanyakan, memodifikasi, atau mempertajam gagasannya. Nilai rata-rata aspek afektif disetiap pertemuan mengalami peningkatan karena peserta didik terlibat secara aktif dalam pembelajaran. Hal tersebut diperkuat dengan penelitian yang dilakukan oleh Rahayu dkk. (2013: 133), yang mengungkapkan bahwa model $P O E$ dapat meningkatkan hasil belajar karena peserta didik dapat menggunakan pengetahuan yang telah dimiliki untuk menjelaskan suatu konsep. Pengalaman peserta didik didapatkan setelah melakukan tahapan observe. Tahapan tersebut menuntut peserta didik melakukan pengujian terhadap hasil 
prediksi sebelumnya, hasil akhir dari tahapan observe kemudian dibahas oleh peserta didik, sehingga peserta didik mendapatkan pengetahuan secara langsung berdasarkan pengalaman mereka sendiri. Nilai rata-rata aspek afektif disetiap pertemuan mengalami peningkatan karena peserta didik terlibat secara aktif dalam pembelajaran.

Konsep modul yang berorientasi $P O E$ berwawasan lingkungan sangat cocok untuk dikembangkan pada materi pencemaran. Hal tersebut tidak terlepas dari materi pencemaran sangat mudah dijumpai dalam kehidupan sehari-hari siswa. Rustaman (2005: 112) mengatakan bahwa penggunaan pendekatan lingkungan berarti mengaitkan lingkungan dalam suatu proses belajar mengajar. Lingkungan digunakan sebagai sumber belajar. Lingkungan merupakan salah satu sumber belajar yang amat penting dan memiliki nilai-nilai yang sangat berharga dalam rangka proses pembelajaran siswa. Penggunaaan lingkungan memungkinkan terjadinya proses belajar yang lebih bermakna sebab anak dihadapkan pada kondisi yang sebenarnya. Dewey cit. Nur (2011: 19) menyatakan bahwa pembelajaran di sekolah seharusnya lebih bermakna, tidak terlalu abstrak. Pembelajaran bermakna yangterbaik dapat diwujudkan dengan meminta siswa berada dalam kelompok-kelompok kecil untuk mengerjakan proyek-proyek pilihan sesuai dengan minat mereka sendiri. Implikasi dari teori Ausubel terhadap pengembangan modul pencemaran berorientasi $P O E$ berwawasan lingkungan adalah modul yang dikembangkan memungkinkan siswa berinteraksi dengan lingkungan sehingga akan diperoleh pengalaman belajar yang bersifat pengetahuan, keterampilan motorik, dan sikap dan kebermaknaan dalam belajar. Pembelajaran biologi yang berorientasi pada lingkungan akan memberi kesempatan siswa memahami proses yang berkaitan dengan lingkungan, hal ini akan menumbuhkan kesadaran keberadaan siswa dalam ekosistemnya.

Implikasi teori belajar Bruner terhadap pengembangan modul $P O E$ adalah dalam tahapan POE siswa didorong untuk melakukan belajar penemuan dalam tahapan observe. Hal tersebut sesuai dengan yang dikemukakan oleh Dahar (1989: 108-109), bahwa dalam belajar penemuan siswa mendapatkan kebebasan untuk menyelediki baik secara perorangan maupun bersama siswa lain untuk memecahkan suatu masalah. 
Pengetahuan yang diperoleh melalui belajar penemuan lebih bertahan lama. Belajar penemuan dapat meningkatkan penalaran dan berpiki secara bebas, serta melatih keterampilan-keterampilan kognitif untuk memecahkan masalah.

Implikasi teori perkembangan kognitif Piaget dalam pembelajaran dapat tercermin dalam bahasa dan cara berpikir siswa. Siswa SMA termasuk dalam perkembangan kognitif tahap operasional formal. Siswa pada tahap tersebut akan berpikir secara logis dan teoritis formal berdasarkan proporsi dan hipotesis serta mampu dalam mengambil keputusan. Perkembangan kognitif pada tahap operasional formal menekankan pada kegiatan siswa yang aktif dalam mengkonstruk pengetahuannya. Guru sebaiknya memberikan kesempatan pada siswa agar belajar sesuai dengan tahap perkembangannya. Guru sebagai fasilitator harus mampu membantu siswa untuk berinteraksi dengan lingkungannya dengan sebaik-baiknya.

Implikasi teori Vygotsky dalam pembelajaran menggunakan modul ini adalah, selain digunakan sebagai bahan ajar mandiri, modul ini juga terintegrasi dalam pembelajaran melalui diskusi dan eksperimen yang dilakukan dalam kelompok kecil. Pemberian bantuan berupa petunjuk, peringatan, dorongan yang dilakukan oleh guru selama tahap awal pembelajaran dilakukan agar semakin lama siswa dapat mengambil alih tanggung jawab secara mandiri. Pengetahuan dibentuk oleh siswa melalui pemecahan masalah yang dikaitkan dengan lingkungan, hal tersebut erat kaitannya dengan pengalaman dalam kehidupan sehari-hari sehingga diharapkan siswa memperoleh pembelajaran yang bermakna.

Hal tersebut sesuai dengan yang dikemukakan oleh Gulo (2004: 135), bahwa metode diskusi kelompok akan membelajarkan siswa agar mampu belajar dengan orang lain, menanggapi pendapat, memelihara kesatuan kelompok, dan belajar tentang teknik-teknik pegambilan keputusan yang berguna dalam kehidupan bermasyarakat. Pengalaman belajar yang demikian tidak akan terjadi jika guru menyajikan pelajaran dengan metode ceramah. Hal tersebut sesuai dengan pendapat Slavin cit. Trianto (2009: 75), yang mengatakan bahwa proses belajar dan pembelajaran siswa harus siswa harus terlibat aktif dan siswa menjadi pusat kegiatan belajar dan pembelajaran di kelas. Pendekatan konstruktivisme dalam pengajaran menerapkan pembelajaran 
kooperatif atas dasar teori bahwa siswa akan lebih mudah menemukan dan memahami konsep-konsep sulit apabila mereka saling mendiskusikan masalahmasalah tersebut dengan temannya.

\section{Kesimpulan}

Kesimpulan yang diperoleh dari penelitian pengembangan ini adalah sebagai berikut:

1. Pengembangan Modul Berorientasi POE Berwawasan Lingkungan Pada Materi Pencemaran dilakukan dengan menggunakan pendekatan penelitian dan pengembangan atau dikenal dengan Research and Development (R\&D) modelBorg dan Gall termodifikasi melalui tahapan-tahapan research and informationcollecting, planning, develop preliminary form of product, preliminary field testing, main product revision, main field testing,dan operational product revision.

2. Kelayakan modul pembelajaran ini mendapatkan nilai 3,3 setelah dilakukan uji coba lapangan dan berkategori "Baik".

3. Pencapaian hasil belajar peserta didik setelah diterapkan modul ini mengalami peningkatan yang cukup signifikan dalam kategori "Sedang".
4. Setelah dilakukan uji secara statistik diperoleh adanya perbedaan hasil belajar siswa, sebelum dan setelah diterapkan modul $P O E$ berwawasan lingkungan.

Mengacu pada hasil dan pelaksanaan penelitian maka direkomendasikan:

1. Modul Berorientasi POE Berwawasan Lingkungan ini dapat diterapkan pada materi pencemaran. Namun, memerlukan persiapan yang baik agar pembelajaran dapat berjalan sesuai dengan rencana yang tercantum di RPP.

2. Modul Berorientasi POE Berwawasan Lingkungan ini dapat dijadikan sebagai salah satu rujukan dalam mengembangkan bahan ajar. Namun, diperlukan keterampilan dalam membuat modul, serta validasi dari ahli-ahli yang kompeten agar dihasilkan modul yang baik.

3. Modul Berorientasi POE Berwawasan Lingkungan menekankan pada pembelajaran penemuan dan pemecahan masalah, sehingga diperlukan sarana penunjang seperti alat dan bahan untuk melakukan kegiatan eksperimen serta pemilihan permasalahan lingkungan yang tepat.

4. Kegiatan eksperimen di dalam modul 
sudah umum digunakan pada materi pencemaran, sehingga guru dapat mengembangkan kegiatan eksperimen lain yang sesuai dengan materi pencemaran.

\section{Daftar Pustaka}

Budiono, E dan Susanto, H. (2006). Penyusunan dan Penggunaan Modul Pembelajaran Berdasar Kurikulum Berbasis Kompetensi Sub Pokok Bahasan Analisa Kuantitatif untuk Soal-Soal Dinamika Sederhana pada Kelas X Semester I SMA. Jurnal Pend. FisikaIndonesia. 4 (2): 79-87.

Depdiknas. (2003). Standar Penilaian BukuPelajaran Sains. Jakarta: Pusat Perbukuan.

$$
\text { (2008). Perangkat }
$$

Pembelajaran KTSP SMA. Jakarta: Direktorat Pembinaan Sekolah Menengah Atas.

Gulo. W. (2008). Strategi Belajar Mengajar. Jakarta: PT. Grasindo.

Millah, ES, Budipramana, LS, dan Isnawati. (2012). Pengembangan Buku Ajar Materi Bioteklogi di Kelas XII SMA IPIEMS Surabaya Berorientasi Sains, Teknologi, Lingkungan, dan Masyarakat (SETS). Jurnal Bio Edu. 1 (1): 1924.

Mundilarto. (2005). Pendekatan Kontekstual dalam Pembelajaran Sains. PPM Terpadu SMPN 2 Mlati. Yogyakarta: 20Agustus 2005.

Nur, M. (2011). Model Pembelajaran Berdasarkan Masalah. Surabaya: UNESA.

Ozdemir, H, Bag, H, \& Bilen, K. (2011).
Effect of Laboratory Activities Designed Based on Prediction, Observation, Explanation (POE) Strategy on Pre Service Science Teachers' Understanding of AcidBase Subject. Western Anatolia Journal of Educational Science: 169174.

Prastowo, A. (2012). Panduan KreatifMembuat Bahan Ajar Inovatif. Yogyakarta: Diva Press.

Rahayu, S, Widodo, AT, dan Sudarmin. (2013). Pengembangan Perangkat Pembelajaran Model POE Berbantuan Media "I am Scientist". Innovatif Journal of Curriculum and Educational Technology. 2(1): 128133.

Rustaman, N, Dirjosoemarto, S, Yudianto, SA, Achmad, Y, Subekti, R, Rochintaniawati, D , dan K. Nurjhani, M. (2005). Strategi Belajar Mengajar Biologi. Bandung: UPIPress.

Sungkono. (2003). Pengembangan Bahan Ajar. Yogyakarta: FIP UNY.

Suratsih. (2010). Pengembangan Modul Pembelajaran Biologi Berbasis Potensi Lokal dalam Kerangka Implementasi KTSP SMA di Yogyakarta. Laporan Hasil Penelitian Unggulan UNY.

Triyanto. (2009). Model Pembelajaran Terpadu: Konsep, Strategi, \& Implementasinya dalam KTSP. Jakarta: Bumi Aksara. 